\title{
Biokonversi Feses Ayam Broiler yang diberi Ransum Mengandung Limbah Jambu Biji Merah sebagai Feed Additive
}

\section{Feces Bioconversion of Broiler Chicken Feeding Containing Red Guava Waste as Feed Additive}

\author{
O. Imanudin* dan D. Widianingrum \\ Program Studi Peternakan, Fakultas Pertanian, Universitas Majalengka, Jawa Barat, 45418 \\ *E-mail: oki_imanudin31@yahoo.co.id
}

(Diterima: 30 Oktober 2017; Disetujui: 21 Desember 2017)

\begin{abstract}
ABSTRAK
Usaha peternakan ayam broiler tidak dapat dipisahkan dari limbah yang dihasilkan sehingga pengolahan limbah harus dilakukan secara efektif dan efisien. Salah satu diantaranya yaitu dengan pengomposan dengan memanfaatkan bioaktivator dari MOL Limbah Jambu Biji Merah (LJBM) guna mempercepat proses penguraian bahan organik. Limbah jambu biji merah ini sebelumnya digunakan sebagai feed additive untuk meningkatkan performa ayam broiler. Dengan perlakuan $\mathrm{R} 0=0 \%, \mathrm{R} 1=1,2 \%, \mathrm{R} 2=2,4 \%$, $\mathrm{R} 3=3,6 \%$ dan $\mathrm{R} 4=4,8 \%$ untuk feed additive terhadap performa ayam broiler dan F0 (feses R0+MOL), F1 (feses R1+MOL), F2 (feses R2+MOL), F3 (feses R3+MOL) dan F4 (feses R4+MOL) untuk penambahan bioaktivator MOL terhadap kualitas kompos. Penelitian ini menggunakan rancangan acak lengkap dengan 5 perlakuan 4 ulangan, perbedaan antar perlakuan menggunakan uji Duncan. Hasil penelitian menunjukan penggunaan tepung LJBM dalam ransum sebagai feed additive berpengaruh nyata terhadap pertambahan bobot badan tetapi tidak berpengaruh nyata terhadap konsumsi dan konversi ransum ayam broiler. Untuk penelitian penambahan bioaktivator MOL LJBM pada pengomposan feses ayam broiler memberikan pengaruh yang nyata terhadap produksi dan kualitas kompos dengan rata-rata N-total 0,89-1,19\%, $\mathrm{P}_{2} \mathrm{O}_{5}$ 0,44-0,62\% dan $\mathrm{K}_{2} \mathrm{O}$ 0,62-1,06\%. Kualitas kompos yang dihasilkan sudah memenuhi standar SNI.
\end{abstract}

Kata kunci: feed additive, kompos, limbah jambu biji merah, mikroorganisme lokal

\section{ABSTRACT}

Broiler farming can not be separated from waste. So that, waste processing must be done effectively and efficiently. One of them is by composting by utilizing bioactivator from MOL of red guava waste (LJBM) to accelerate the process of decomposition of organic matter. This red guava waste was previously used as feed additive to improve the performance of broiler. With $R O=0 \%$ treatment, $R 1=1.2 \%, R 2=2.4 \%$, $R 3=3.6 \%$ and $R 4=4.8 \%$ as feed additive to broiler performance and $F 0$ (feces $R 0+M O L$ ), F1 (feces $R 1+M O L$ ), F2 (feces R2+MOL), F3 (stool R3+MOL) and F4 (feces R4+MOL) as the addition of MOL bioactivator to compost quality. This study used a complete randomized design with 5 treatment and 4 replications. The difference between treatments used Duncan test. The results showed that the use of LJBM flour in ration as feed additive had significant effect on the body weight gain but has no significant effect on consumption and conversion of broiler chicken ration. For the research of the addition of bio-activator MOL LJBM in composting broiler feces has a significant effect on production and quality of compost with average $\mathrm{N}$-total $0.89-1.19 \%, \mathrm{P}_{2} \mathrm{O}_{5} 0.44-0.62 \%$ and $\mathrm{K}_{2} \mathrm{O}$ 0.62-1.06\%. The resulting compost quality meets the National Standardization of Indonesia (SNI).

Keywords: compost, feed additive, local microorganism, red guava waste

\section{PENDAHULUAN}

Usaha peternakan ayam broiler selain menghasilkan daging sebagai komoditas utamanya, juga menghasilkan dampak negatif berupa limbah kotoran ayam yang menimbulkan gas berbau seperti amonia, nitrat, nitrit dan gas hidrogen sulfida yang 
terbentuk selama proses dekomposisi. Udara yang tercemar gas amonia dan sulfida dapat menimbulkan gangguan kesehatan terhadap manusia yang tinggal di lingkungan sekitar peternakan maupun terhadap ternak itu sendiri yang dapat menyebabkan gangguan kesehatan sehingga produktivitasnya menurun.

Pengolahan feses ayam broiler antara lain dengan cara pengomposan. Pengomposan adalah cara pengolahan limbah organik dengan menguraikannya menjadi unsur-unsur yang tidak berbahaya dan mudah diserap oleh tanah. Produk dari proses pengomposan dapat diaplikasikan langsung ke tanah sebagai pupuk organik yang mengandung nutrisi seperti kalium, nitrat, natrium, kalsium, magnesium dan klorida untuk pertumbuhan tanaman (Khan dan Ishaq, 2011).

Feses ayam broiler merupakan bahan organikyangcukupsulitdirombak dalamwaktu singkat. Oleh karena itu untuk mempersingkat waktu, maka proses pengomposan dilakukan dengan menambahkan aktivator kedalam bahan komposan. Aktivator merupakan bahan organik yang dapat mempercepat proses pengomposan atau perombakan bahanbahan organik. Mikroba-mikroba lokal yang dihasilkan dari campuran bahan-bahan organik tersebut disebut dengan Mikroorganisme Lokal (MOL).

MOL merupakan salah satu dekomposer yang dapat mempercepat proses pengomposan (Saravanan et al., 2013; Sharma et al., 2014; Mbouobda et al., 2014) dan dapat meningkatkan mutu kompos. Salah satu bahan yang dapat digunakan sebagai dekomposer yaitu limbah jambu biji merah (LJBM) menjadi MOL.

Limbah jambu biji merah merupakan sisa dari penjualan jambu biji merah dengan alasan pengafkiran karena memar, terlalu matang, ada ulatnya. Limbah jambu biji merah terdiri atas daging dan biji buah.

Jambu biji merah mengandung gizi yang lengkap antara lain energi 49 kalori, protein 0,90 gram, lemak 0,30 gram, karbohidrat 12,20 gram, vitamin A 25 SI dan vitamin C
$87 \mathrm{mg}$ (Arianingrum, 2014). Kandungan vitamin yang cukup tinggi merupakan sumber antioksidan yang baik.

Limbah jambu biji dalam bentuk segar tidak higienis karena banyak mengandung hama dan penyakit antara lain semut, tikus, ganggang (Cihephaleusos vieccons), jamur (Ceroospora psidil) dan ulat baik ulat putih, ulat keket dan ulat jengkal (Tim BPP Teknologi, 2014). Semut dan tikus dapat memakan dan menghabiskan buah jambu biji merah serta menyisakan penyakit pes.

Pengolahan limbah jambu biji merah yang sederhana, contohnya dikeringkan dan dihaluskan menjadi tepung limbah jambu biji merah (LJBM). Tepung LJBM dapat diberikan sebagai feed additive dalam ransum ayam broiler berfungsi untuk memperbaiki kualitas produksi ayam broiler. Senyawa eugenol dapat merangsang selaput lendir perut besar dan usus sehingga membantu kerja enzim pencernaan. Hal demikian menyebabkan laju pakan meningkat dan seiring dengan laju pertumbuhan maka produksi daging akan naik.

Melalui pemanfaatan dua jenis limbah ini maka dapat menciptakan lingkungan yang nyaman dengan cara memanfaatkan limbah jambu biji merah sebagai feed additive untuk mempertahankan produktivitas ayam broiler dan sebagai MOL dalam mendekomposisi limbah peternakan ayam broiler tersebut menjadi kompos. Kompos ini digunakan sebagai pupuk organik yang kaya akan sumber nutrisi bagi tanaman jambu, sehingga sistem pertanian yang terintegrasi dengan peternakan dapat terwujud.

Berdasarkan uraian diatas maka perlu dilakukan penelitian tentang Biokonversi Limbah Feses Ayam Broiler yang diberi Ransum Mengandung Limbah Jambu Biji Merah (Psidium guajava L) sebagai Feed Additive. 


\section{METODE}

\section{Penelitian Tahap I}

Penelitian ini meliputi pengolahan limbah jambu biji merah menjadi:

a. Tepung limbah jambu biji merah yang akan digunakan sebagai feed additive dalam pakan ayam broiler pada penelitian Tahap II. Bahan penelitian menggunakan limbah jambu biji merah dari kelompok tani di Kecamatan Panyingkiran Kabupaten Majalengka.

Prosedur pengeringan limbah jambu biji merah yaitu :

$>$ Limbah jambu biji merah dalam bentuk segar dibersihkan

$>$ LJBM dipotong menjadi bagian yang lebih kecil dan homogen

$>$ LJBM dikeringkan menggunakan oven

$>$ LJBM kering dihaluskan menjadi tepung

$>$ Analisis proksimat tepung LJBM untuk mengetahui kualitas kimianya.

b. Mikroorganisme Lokal (MOL) LJBM digunakan sebagai Bioaktivator dalam pengomposan feses ayam broiler pada penelitian tahap III. Prosedur Pembuatan Larutan MOL sebagai berikut:

$>1 \mathrm{Kg}$ limbah jambu biji merah diiris-iris hingga menjadi potongan potongan kecil dan masukan kedalam ember plastik, setiap lapisan setebal $10 \mathrm{~cm}$ dan taburkan garam sampai rata

$>$ Air cucian beras ditambahkan sebanyak 1 liter

> Gula ditambahkan sebanyak 200 gram dan diaduk hingga rata

$>$ Ember ditutup rapat dengan plastik dan diatasnya diberi air sehingga tampak plasik cekung terisi air, setelah 30 hari baru dibuka, akan tampak cairan berwarna kuning kecoklatan.

\section{Penelitian Tahap II}

Penelitian ini meliputi pemeliharaan ayam broiler dengan pemberian pakan menggunakan ransum yang ditambahkan feed additive mengandung tepung LJBM.

\section{a. Ayam Penelitian}

Ayam penelitian menggunakan ayam broiler finalstock strain Cobb sebanyak 100 ekor berumur 1 hari. Ayam dibagi secara acak ke dalam 20 unit kandang, tanpa pemisahan jenis kelamin (straight run), setiap kandang berisi 5 ekor ayam, dan untuk memudahkan pencatatan setiap ayam diberi nomor.

\section{b. Kandang dan Peralatan}

Kandang yang digunakan berukuran panjang $100 \mathrm{~cm}$, lebar $50 \mathrm{~cm}$ dan tinggi 75 $\mathrm{cm}$. tempat pakan dan tempat minum dari bahan plastik, pemanas dari bohlam 40 watt sebanyak 20 buah untuk 20 unit kandang. Timbangan Ohause kapasitas 2160 gram dengan ketelitian dua angka dibelakang koma

\section{c. Ransum Penelitian}

Ransum penelitian disusun dengan kandungan protein $22 \%$ dan energi metabolis $3000 \mathrm{kkal} / \mathrm{kg}$ (Daghir, 1995).

\section{Penelitian Tahap III}

Penelitian ini yaitu pengomposan feses ayam broiler yang dihasilkan dari penelitian tahap II dengan prosedur sebagai berikut:

$>$ Penimbangan bahan komposan (feses ayam broiler)

$>$ Bahan komposan yang telah ditimbang dimasukkan kedalam bak plastik dan diaduk sampai homogen, semprotkan MOL LJBM yang telah dicampur air lalu diaduk secara merata

$>$ Setiap bak pengomposan diberi identitas sesuai dengan perlakuan yang diberikan.

> Selama proses berlangsung dilakukan pengukuran suhu komposan setiap hari dan pengadukan komposan pada masingmasing bak setiap tiga hari sekali.

Peubah yang diamati:

1. Performa ayam broiler meliputi: Pertumbuhan bobot badan Konsumsi Ransum dan Konversi Ransum. 
2. Produksi dan Kualitas Kompos meliputi: kandungan $\mathrm{N}$-total, $\mathrm{P}_{2} \mathrm{O}_{5}$ dan $\mathrm{K}_{2} \mathrm{O}$.

Penelitian dilakukan secara eksperimen menggunakan Rancangan Acak Lengkap (RAL), dengan perlakuan penelitian tahap II Penggunaan tepung LJBM sebagai feed additive dalam ransum sebanyak 5 perlakuan $\mathrm{R} 0=0 \%, \mathrm{R} 1=1,2 \%, \mathrm{R} 2=2,4 \%, \mathrm{R} 3=3,6 \%$ dan $\mathrm{R} 4=4,8 \%$ masing-masing perlakuan diulang 4 kali. Penelitian tahap III Penggunaan bioaktivator MOL LJBM dalam proses pengomposansebanyak 5 perlakuan F0 (feses R0+MOL), F1 (feses R1+MOL), F2 (feses R2+MOL), F3 (feses R3+MOL) dan F4 (feses $\mathrm{R} 4+\mathrm{MOL}$ ) setiap perlakuan diulang 4 kali.

\section{Analisis Data}

Data yang diperoleh dianalisis statistik dengan menggunakan sidik ragam dan untuk mengetahui perbedaan antar perlakuan dilakukan Uji Duncan

\section{HASIL DAN PEMBAHASAN}

\section{Pertambahan Bobot Badan, Konsumsi Ransum dan Konversi Ransum}

Tabel 1 menunjukkan bahwa pemberian tepung limbah jambu biji merah sebagai feed additive pada ransum tidak menunjukan perbedaan dengan kontrol (R0) untuk semua parameter yang diamati. Pertambahan bobot badan ayam broiler yang diberi ransum mengandung tepung limbah jambu biji merah sebagai feed additive dengan konsentrasi yang diujikan sebesar $(1,2-4,8 \%)$ tidak berbeda nyata $(\mathrm{P}>0,05)$ dengan kontrol $(0 \%$ LJBM). Meskipun demikian Pertambahan Bobot Badan tertinggi terhadap kontrol dihasilkan pada R4 (4,8\% Tepung LJBM). Perlakuan ini berbeda nyata $(\mathrm{P}<0,05)$ lebih tinggi dibandingkan dengan pemberian tepung pada konsentrasi R1 (1,2\%), R2 $(2,4 \%)$ dan R3 $(3,6 \%)$. Hal ini disebabkan kandungan ransum perlakuan yang diberikan memiliki kandungan vitamin $\mathrm{C}$ seperti yang dilaporkan oleh Parimin (2005) bahwa dalam $100 \mathrm{~g}$ jambu matang mengandung vitamin C sebesar $150,5 \mathrm{mg}$. Selain mengandung vitamin $\mathrm{C}$, jambu biji merah juga banyak mengandung likopen. Likopen merupakan karotenoid yang sangat dibutuhkan oleh tubuh dan merupakan salah satu antioksidan yang sangat kuat (Biskrisima et al., 2014), Selain itu tepung LJBM mengandung flavoniod yang merupakan antioksidan. Flavonoid juga dapat mengaktifkan kinerja vitamin C sebagai antioksidan utama (Telci et al., 2006), sehinggapemberian tepung LJBM ini mempengaruhi Pertambahan bobot badan yang dihasilkan.

Sejalan dengan hasil penelitian Cooper and Washburn (1998) dalam Biskrisima, et al. (2014) menjelaskan peran vitamin C dalam metabolisme protein sebagai antioksidan yaitu vitamin $C$ mempunyai peran kontribusi terhadap sintesis protein dan menghambat laju katabolisme protein, sehingga mengurangi produksi panas tubuh karena katabolisme dapat memicu peningkatan panas tubuh. Kondisi tersebut memberikan rasa nyaman pada broiler.

Menurut Suthama (2010) dalam Biskrisima, et al. (2014) menjelaskan bahwa pertumbuhan berdasarkan metabolisme protein melibatkan dua proses yaitu sintesis (anabolis) dan pemecahan atau degradasi (katabolis). Hubungan antara sintesis dan degradasi merupakan dua proses yang selalu bertentangan disebut protein turnover (siklus tukar protein). Laju deposisi protein dalam daging mempunyai kontribusi yang sangat besar terhadap pertumbuhan.

Konsumsi ransum dan konversi ransum tidak menunjukan perbedaan. Pemberian tepung limbah jambu biji merah sebagai feed additive sebesar $1,2 \%-4,8 \%$ tidak berbeda dengan kontrol (ayam broiler yang diberi ransum tanpa mengandung LJBM (0\%). Tidak adanya pengaruh yang nyata pada perlakuan hal ini diindikasikan karena bentuk ransum dan tepung limbah jambu biji merah yang diberikan semua perlakuan sama dalam bentuk tepung. Penelitian ini diperkuat oleh pendapat Rasyaf (2008) bahwa ransum ayam pedaging dipengaruhi oleh bentuk ransum yang diberikan. Selain itu penambahan 
Tabel 1. Pengaruh perlakuan terhadap pertambahan bobot badan, konsumsi ransum dan konversi ransum.

\begin{tabular}{lccc}
\hline Perlakuan & $\begin{array}{c}\text { Pertambahan Bobot } \\
\text { Badan }(\mathrm{g})\end{array}$ & $\begin{array}{c}\text { Konsumsi } \\
\text { Ransum }(\mathrm{g})\end{array}$ & Konversi Ransum \\
\hline R0 (0\% Tepung LJBM) & $1848,13^{\mathrm{ab}}$ & $2289,26^{\mathrm{a}}$ & $1,24^{\mathrm{a}}$ \\
R1 (1,2\% Tepung LJBM) & $1833,96^{\mathrm{b}}$ & $2297,03^{\mathrm{a}}$ & $1,25^{\mathrm{a}}$ \\
R2 (2,4 \% Tepung LJBM) & $1847,63^{\mathrm{ab}}$ & $2330,24^{\mathrm{a}}$ & $1,26^{\mathrm{a}}$ \\
R3 (3,6\% Tepung LJBM) & $1857,57^{\mathrm{ab}}$ & $2278,84^{\mathrm{a}}$ & $1,23^{\mathrm{a}}$ \\
R4 (4,8\% Tepung LJBM) & $1883,01^{\mathrm{a}}$ & $2312,29^{\mathrm{a}}$ & $1,23^{\mathrm{a}}$ \\
\hline
\end{tabular}

Ket: Superskript yang berbeda pada kolom yang sama menunjukan perbedaan yang nyata $(\mathrm{P}<0,05)$

tepung LJBM dalam persentase yang sedikit dalam ransum tidak mempengaruhi komposisi nutrisi yang terkandung di dalam ransum. Hal ini sejalan dengan hasil penelitian Adityo et al. (2013) bahwa tidak adanya perbedaan yang nyata terhadap bobot hidup dan pertambahan bobot badan ayam broiler disebabkan karena konsmsi yang kecil maka kandungan vitamin $\mathrm{C}$ dan likopen dalam tepung jambu biji merah yang terserap juga sedikit sehigga tidak memberi pengaruh yang maksimal. Selain itu bobot badan ayam broiler pada penelitan ini memiliki bobot lebih rendah dibandingkan dengan standar, ini disebabkan karena ransum yang dikonsumsi relative rendah kemudian faktor lainnya adalah suhu lingkungan pada saat penelitian relative tinggi sekitar320C sehingga untuk menstabikan suhu tubuhnya ayam broiler akan mengurangi konsumsi ransum. Hal ini sejalan dengan Mashaly et al. (2004) bahwa cekaman panas (heat stress) menyebabkan gangguan terhadap pertumbuhan pada ayam broiler. Sebelumnya Kuczynski (2002) mengungkapkan bahwa pemeliharaan ayam broiler sampai umur 35 hari pada suhu di atas $31^{\circ} \mathrm{C}$ dapat menyebabkan penurunan bobot badan mencapai $25 \%$.

\section{Produksi dan Penyusutan Kompos}

Tabel 2 menunjukan bahwa terdapat perbedaan rataan produksi kompos pada berbagai perlakuan, rataan produksi kompos terendah dicapai pada perlakuan F1 (Feses ayam broiler yang diberi ransum R1 $+200 \mathrm{ml}$ MOL LJBM) yaitu sebesar 623,1 gram dan rataan tertinggi dicapai pada perlakuan F4 (Feses ayam broiler yang diberi ransum R4
+ $200 \mathrm{ml}$ MOL LJBM) yaitu sebesar 907,05 gram. Hal ini membuktikan bahwa semakin tinggi kandungan limbah jambu biji merah dalam feed additive pada ransum ayam broiler maka produksi komposan akan semakin besar, hal ini diduga dari kandungan ransum yang kaya akan kandungan $\mathrm{N}$ dan penambahan feed additive mengandung tepung limbah jambu biji merah kaya akan sumber $\mathrm{C}$ sehingga akan menghasilkan nisbah $\mathrm{C} / \mathrm{N}$ ideal bagi pertumbuhan mikroorganisme selamaproses pengomposan berlangsung.

Sehingga penambahan MOL pada pengomposan mengakibatkan proses penguraian bahan oganik semakin cepat. Hal ini sejalan dengan penelitian Mbouobda et al. (2014) bahwa penambahan effective microorganism pada proses pengomposan dapat mempercepat proses pengomposan.

Hasil produksi kompos yang rendah menandakan bahwa proses pengomposan berjalan dengan baik. Nisbah $\mathrm{C} / \mathrm{N}$ yang terlalu tinggi atau terlalu rendah dapat menghambat pertumbuhan mikroorganisme, sehingga proses pengomposan dapat terganggu dan berjalan lambat hal ini berpengaruh terhadap produksi kompos yang dihasilkan, seperti dilaporkan dari hasil peneitian Musnawar (2007) bahwa di dalam pengomposan akan terjadi perubahan yang dilakukan oleh mikroorganisme, yaitu berupa penguraian selulosa, hemiselulosa, lemak, serta bahan lainnya menjadi karbondioksida $\left(\mathrm{CO}_{2}\right)$ dan air. Dengan adanya perubahan-perubahan tersebut, maka bobot dan isi bahan dasar kompos akan menjadi berkurang antara 40 
Tabel 2. Pengaruh perlakuan terhadap produksi dan penyusutan kompos

\begin{tabular}{lccccc}
\hline \multirow{2}{*}{ Peubah } & \multicolumn{5}{c}{ Perlakuan } \\
\cline { 2 - 6 } & F0 & F1 & F2 & F3 & F4 \\
\hline Berat Awal Kompos & 1500,00 & 1500,00 & 1500,00 & 1500,00 & 1500,00 \\
Produksi Kompos (g) & $717,45^{\text {ab }}$ & $623,10^{\mathrm{a}}$ & $662,85^{\mathrm{a}}$ & $796,20^{\mathrm{b}}$ & $907,05^{\mathrm{c}}$ \\
Penyusutan Kompos (\%) & $52,17^{\mathrm{ab}}$ & $58,46^{\mathrm{a}}$ & $55,81^{\mathrm{a}}$ & $46,92^{\mathrm{b}}$ & $39,53^{\mathrm{c}}$ \\
\hline
\end{tabular}

$-60 \%$, tergantung bahan dasar kompos dan proses pengomposannya, sedangkan menurut Yuwono (2005), pengomposan secara aerobik akan mengurangi bahan komposan sebesar 50 $\%$ dari bobot awalnya.

CSIRO (1979) mengemukakan bahwa nisbah $\mathrm{C} / \mathrm{N}$ yang terlalu tinggi menyebabkan laju pengomposan berjalan lambat dan dapat menyebabkan kondisi pengomposan menjadi asam, sedangkan bila terlalu rendah menyebabkan terjadinya kehilangan nitrogen dalam bentuk gas amonia, akibatnya dapat meracuni dan mematikan jenis mikroba yang diperlukan dalam proses pengomposan.

Berdasarkan hasil Uji Duncan (Tabel 2) memperlihatkan bahwa perlakuan F1 menghasilkan produksi komposan yang nyata lebih rendah dibandingkandengan produksi komposan pada perlakuan $\mathrm{F} 0$, F2, F3 dan F4, produksi komposan yang dihasilkan dari perlakuan F2 nyata lebih rendah dibandingkan dengan perlakuan $\mathrm{F} 0$, F3 dan F4, demikian pula produksi komposan yang dihasilkan dari perlakuan F0 nyata lebih rendah dibandingkan dengan perlakuan $\mathrm{F} 3$ dan F4, hal ini menunjukkan bahwa semakin tinggi kadar $\mathrm{C} / \mathrm{N}$ pada pengomposan artinya semakin banyak kandungan limbah jambu biji merah pada feed additive dalam pakan ayam broiler yang digunakan, mengakibatkan mikroba kesulitan mencerna bahan tersebut karena limbah jambu biji merah banyak mengandung unsur $\mathrm{C}$.

Hasil penelitian rataan penyusutan bahan komposan pada berbagai perlakuan terhadap penyusutan komposan (Tabel 2), menunjukan bahwa rataan penyusutan terendah komposan pada berbagai perlakuan terjadi pada $\mathrm{F} 4$ sebesar $39.53 \%$, dan rataan penyusutan tertinggi dicapai pada perlakuan
F1 yaitu sebesar $58.46 \%$.

Hasil analisis statistik pengaruh perlakuanterhadap penyusutan komposan menunjukkan pengaruh nyata $(\mathrm{P}<0,05)$. Uji lanjut menggunakan uji Duncan menunjukkan bahwa F1 nyata lebih tinggi $(\mathrm{P}<0,05)$ dibandingkan dengan perlakuan F2, F0, F3 dan F4. Perlakuan F2 nyata lebih tinggi $(\mathrm{P}<0,05)$ dibandingkan dengan perlakuan F0, F3 dan F4. Perlakuan F0 nyata lebih tinggi dibandingkan dengan perlakuan F3 dan F4. Berdasarkan pernyataan Isroi (2008), bahwa terjadi penyusutan volume/ bobot kompos seiring dengan kematangan kompos. Perbedaan pemberian feed additive yang mengandung limbah jambu biji merah dalam ransum dan penambahan bioaktivator (mol) limbah jambu biji merah memberikan pengaruh yang nyata terhadap penyusutan bahan komposan limbah feses ayam broiler, hal ini disebabkan proses pengomposan sangat dipengaruhi oleh kadar unsur $\mathrm{C}$ dan $\mathrm{N}$ yang tersedia dalam bahan komposan.

Besarnya penyusutan tergantung pada karakteristik bahan mentah dan tingkat kematangan kompos. Lebih lanjut Siregar (2012), menjelaskan bahwa dengan semakin bertambahnya dekomposer yang diberikan maka proses perombakan akan lebih mudah dan lebih banyak hasil yang terdekomposisi oleh aktivator tersebut.

Hal ini berkaitan dengan aktivitas mikoorganisme yang memerlukan unsur karbon dan nitrogen dalam jumlah yang seimbang untuk melakukan perombakan bahan komposan, karena pada kondisi ideal kadar $\mathrm{C}$ dan $\mathrm{N}$ terpenuhi, maka aktivitas mikroorganisme dalam merombak bahan organik dalam bahan komposan akan berjalan dengan baik. 
Tabel 3. Pengaruh perlakuan terhadap rataan N-Total, $\mathrm{P}_{2} \mathrm{O}_{5}$ dan $\mathrm{K}_{2} \mathrm{O}$

\begin{tabular}{lccc}
\hline Perlakuan & Rataan N-total & Rataan $\mathrm{P}_{2} \mathrm{O}_{5}$ & Rataan $\mathrm{K}_{2} \mathrm{O}$ \\
\hline F0 & $0.73^{\mathrm{e}}$ & $0.41^{\mathrm{d}}$ & $0.62^{\mathrm{d}}$ \\
F1 & $1.12^{\mathrm{b}}$ & $0.48^{\mathrm{c}}$ & $0.85^{\mathrm{c}}$ \\
F2 & $1.19^{\mathrm{a}}$ & $0.56^{\mathrm{b}}$ & $1.06^{\mathrm{a}}$ \\
F3 & $0.89^{\mathrm{d}}$ & $0.62^{\mathrm{a}}$ & $1.04^{\mathrm{a}}$ \\
F4 & $1.04^{\mathrm{c}}$ & $0.44^{\mathrm{d}}$ & $0.97^{\mathrm{b}}$ \\
\hline
\end{tabular}

Keterangan: Superskript yang berbeda pada kolom yang sama menunjukan perbedaan yang nyata $(\mathrm{P}<0,05)$

Ditunjang oleh pendapat Musnamar (2007), bahwa di dalam proses pengomposan akan terjadi perubahan struktur bahan organik yang dilakukan oleh mikroorganisme, yaitu berupa penguraian selulosa, hemiselulosa, lemak, lilin, serta yang lainnya menjadi karbondioksida $\left(\mathrm{CO}_{2}\right)$ dan air. Dengan adanya perubahan-perubahan tersebut, maka bobot dan isi bahan dasar kompos akan menjadi berkurang antara $40-60 \%$ dan tergantung bahan dasar kompos dan proses pengomposannya. Hasil dari penelitian yang dilakukan menunjukkan bahwa persentase penyusutan bahan komposan yang terjadi berkisar antara 39,53\% - 58,46\%. Hal ini menunjukkan bahwa proses pengomposan berjalan dengan baik.

\section{Kandungan N-Total, $\mathrm{P}_{2} \mathrm{O}_{5}$ dan $\mathrm{K}_{2} \mathrm{O}$ Kandungan N-total}

Hasil analisis statistik pengaruh perlakuan terhadap kandungan $\mathrm{N}$-total menunjukkan pengaruh nyata $(\mathrm{P}<0,05)$. Uji lanjut menggunakan uji Duncan menunjukkan bahwa F2 nyata lebih tinggi $(\mathrm{P}<0,05)$ dibandingkan dengan perlakuan F0, F1, F3 dan F4. Perlakuan F1 nyata lebih tinggi $(\mathrm{P}<0,05)$ dibandingkan dengan perlakuan $\mathrm{F} 0$, F3 dan F4. Perlakuan F4 nyata lebih tinggi dibandingkan dengan perlakuan F0 dan F3.

Tabel 3 menunjukan bahwa kompos dengan kandungan $\mathrm{N}$ tertinggi dihasilkan dari perlakuan F2 sebesar 1,19 yang dihasilkan dari feses ayam yang diberi pakan ransum yang mengandung tepung limbah LJBM sebesar $2,4 \%$ artinya pemberian Tepung LJBM pada ransum dan penambahan MOL LJBM pada bahan komposan ini dapat meningkatkan jumlah $\mathrm{N}$ dalam komposan dibandingkan dengan feses control (tanpa penambahan tepung LJBM). Ini diduga karena kandungan Vitamin C pada LJBM yang berperan sebagai antioksidan dalam metabolisme protein seperti dikemukakan oleh Cooper and Washburn (1998) dalam Biskrisima (2014) menjelaskan peran vitamin $C$ dalam metabolisme protein sebagai antioksidan yaitu vitamin $\mathrm{C}$ mempunyai peran kontribusi terhadap sintesis protein dan menghambat laju katabolisme protein

Kandungan N-total dalam kompos diperoleh dari hasil degradasi bahan organik komposan oleh mikroorganisme dan organisme yang mendegradasi bahan komposan (Hidayati et al., 2008). Starbuck, (2004) mengemukakan bahwa organisme yang bertugas dalam menghancurkan material organik membutuhkan nitrogen $(\mathrm{N})$ dalam jumlah yang besar. Nitrogen akan bersatu dengan mikroba selama proses penghancuran material organik. Setelah proses pembusukan selesai, nitrogen akan dilepaskan kembali sebagai salah satu komponen yang terkandung dalam kompos.

Tersedianya nitrogen dalam jumlah yang tinggi karena terjadi proses dekomposisi yang lebih sempurna, kandungan nitrogen yang tinggi berasal dari bahan kompos yang digunakan berasal dari feses ayam broiler yang diberi pakan ransum yang banyak mengandung protein, selain itu peningkatan kandungan $\mathrm{N}$ diduga karena bioaktivator yaitu aktivitas mikroorganisme yang berasal dari MOL limbah jambu biji merah (Psidium guajava $\mathrm{L}$ ) yang ditambahkan selama proses pengomposan. 
Adanya aktivitas mikroorganisme pada MOL LJBM ditambah persediaan oksigen yang cukup membuat terjadinya peningkatan kandungan $\mathrm{N}$ baik nitrat maupun total. namun jika salah satu dari proses tersebut tidak tersedia atau kurang maka akan menyebabkan terjadinya proses denitrifikasi oleh bakteri Thiobacillusdenitrificans, yang membuat unsur hara $\mathrm{N}$ akan mengalami penurunan akibat pelepasan nitrogen keudara (Rao,1994). Hal ini yang menyebabkan kandungan $\mathrm{N}$ pada kompos hasil pengomposan limbah feses ayam broiler yang diberi ransum mengandung limbah jambu biji merah (Psidium guajava L) Sebagai feed additive berbeda-beda pada masing-masing perlakuan. Hal ini diperkuat degan pernyataan Dominguez and Edwards (2011) bahwa Mineralisasi nitrogen organik adalah parameter yang peting untuk menentukan kandungan nitrogen yang terdegradasi, dan berkaitan dengan kematangan kompos. Akibatnya, pada tahap awal degradasi fermentasi bahan organik menyebabkan suhu menjadi tinggi. Kemudian, setelah terjadi penurunan aktivitas biologis, suhu pengomosan menjadi menurun dan menghasilkan produk akhir yang stabil.

\section{Kandungan $\mathrm{P}_{2} \mathrm{O}_{5}$}

Hasil analisis statistik pengaruh perlakuan terhadap kandungan $\mathrm{P}_{2} \mathrm{O}_{5}$ menunjukkan pengaruh nyata $(\mathrm{P}<0,05)$. Uji lanjut menggunakan uji Duncan menunjukkan bahwa F3 nyata lebih tinggi $(\mathrm{P}<0,05)$ dibandingkan dengan perlakuan F0, F1, F2 dan F4. Perlakuan F2 nyata lebih tinggi $(\mathrm{P}<0,05)$ dibandingkan dengan perlakuan $\mathrm{F} 0$, F1 dan F4. Perlakuan F1 nyata lebih tinggi dibandingkan dengan perlakuan $\mathrm{F} 0$ dan $\mathrm{F} 4$. F0 tidak berbeda nyata dengan F4.

Perbedaan kandungan $\mathrm{P}_{2} \mathrm{O}_{5}$ pada masing-masing perlakuan diduga berhubungan dengan kandungan $\mathrm{N}$ dalam bahan komposan. Bahan komposan dalam penelitian ini yaitu feses ayam yang diberi ransum mengandung limbah jambu biji merah (Psidium guajava $\mathrm{L}$ ) sebagai feed additive, kandungan $\mathrm{P}_{2} \mathrm{O}_{5}$ yang paling tinggi dihasilkan dari F3 yaitu feses ayam broiler yang beri ransum mengandung tepung LJBM sebesar 3,6\% hal ini dapat diasumsikan bahwa bahan komposan memiliki kandungan $\mathrm{N}$ yang cukup tinggi serta adanya vitamin $\mathrm{C}$ yang dapat membantu proses metabolisme protein (Cooper and Washburn, 1998). Mikroba menggunakan Nitrogen dalam bentuk ammonium, nitrat, asam amino dan protein. Semakin besar nitrogen yang dikandung maka multiplikasi mikroorganisme yang merombak fosfor akan meningkat, terlebih bahan tambahan dalam proses pengomposanmenggunakan Bioaktivator MOL yang kaya akan sumber mikroorganisme sehingga dapat mempercepat proses perombakan bahan-bahan organik, hal ini mengakibatkan kandungan fosfor dalam bahan kompos juga meningkat. Kandungan fosfor yang berada dalam bahan komposan akan digunakan oleh sebagian besar mikroorganisme untuk membangun selnya. Hal ini sejalan dengan pendapat Khan (2001) dalam Hidayati et al. (2008) yang menyatakan bahwa unsur P sangat diperlukan oleh mikroorganisme untuk membangun selnya, seperti pembentukan protoplasma dan inti sel. Perombakan bahan organik dan proses asimilasi fosfor terjadi karena adanya enzim fosfatase yang dihasilkan oleh sebagian mikroorganisme.

\section{Kandungan $\mathrm{K}_{2} \mathrm{O}$}

Hasil analisis statistik pengaruh perlakuan terhadap kandungan K2O menunjukkan pengaruh nyata $(\mathrm{P}<0,05)$. Uji lanjut menggunakan uji Duncan menunjukkan bahwa F2 tidak berbeda nyata dengan F3 dan nyata lebih tinggi $(\mathrm{P}<0,05)$ dibandingkan dengan F0, F1 dan F4. Perlakuan F4 nyata lebih tinggi $(\mathrm{P}<0,05)$ dibandingkan dengan perlakuan F0 dan F1. Perlakuan F1 nyata lebih tinggi dibandingkan dengan perlakuan F0.

Kalium hanya berperan dalam membantu pembentukan protein dan karbohidrat. Kalium tidak terdapat dalam protein, protoplasma dan sellulosa, elemen ini bukan elemen langsung dalam pembentukan bahan organik. Kalium yang terkandung dalam kompos pada masing-masing perlakuan berbeda walaupun semua perlakuan 
ditambahakan bioaktivator MOL LJBM yang sama sebanyak $200 \mathrm{ml}$, namun bahan baku berbeda yaitu dari feses yang diberi tepung LJBM dengan tingkat pemberian berbeda. Pemberian bioaktivator MOL LJBM ini diduga salah satu faktor yang mempegaruhi perbedaan kandungan $\mathrm{K}$ dalam kompos. Hal ini sejalan dengan hasil penelitian Nur et al. (2012) yang melapokan bahwa unsur $\mathrm{K}$ akan dimanfaatkan oleh mikroba dalam proses dekomposisi sehingga semakin banyak penambahan bioaktivator EM maka akan semakin banyak pemanfaatan $\mathrm{K}$ oleh mikroba.

Aktivitas bakteri yang terkandung dalam bioaktivator MOL LJBM ini sangat berpengaruh terhadap peningkatan kandungan kalium. Kalium diikat dan disimpan dalam sel oleh bakteri dan jamur, jika didekomposisi kembali maka kalium akan menjadi tersedia kembali. Seperti yang dikemukakan Sutedjo (1996) bahwa kalium digunakan oleh mikroorganisme sebagai katalisator.

\section{KESIMPULAN}

Berdasarkan hasil penelitian dapat disimpulkan bahwa:

1. Pemberian tepung LJBM sebagai feed additive pada ransum ayam broiler berpengaruh nyata $(\mathrm{P}<0,05)$ terhadap pertambahan bobot badan, tetapi tidak berpengaruh nyata $(\mathrm{P}>0,05)$ terhadap konsumsi dan konversi ransum ayam broiler.

2. Penambahan bioaktivator mol LJBM pada pengomposan feses ayam broiler yang diberi ransum mengandung LJBM sebagai feed additive berpengaruh nyata $(\mathrm{P}<0,05)$ terhadap produksi dan kualitas kompos.

\section{DAFTAR PUSTAKA}

Badan Standardisasi Nasional (BSN). 2004. Spesifikasi Kompos dari Sampah Organik Domestik. SNI 19-7030-2004.

H. Adityo., L.D. Mahfudz dan V. D. Y. B.
Ismadi. 2013. Pengaruh Penggunan Tepung Buah Jambu Biji Merah (Psidium guajava L.) Dalam Ransum Terhada Perlemakan Ayam Broiler. Anima AgriculturalJurnal, Vol. 2. No.2 Hal 41-48.

Hidayati Y. A., E. Harlia dan E. T. Marlina. 2008. Upaya Pengolahan Feses Domba dan Limbah Usar (Vitiveria Zizanioides) Melalui Berbagai Metode Pengomposan. Jurnal Ilmu Ternak, Vol. 8, No. 1, Hal 87 - 90.

CSIRO Division of Soils. 1979. Composting Making Soil Improver From Rubbish. Discovering Soils. No.3.

Daghir, N. J. 1995. Poultry Production in Hot Climates. UK at The University Press, Cambridge.

Dominguez. J and C. A. Edwards, 2011. "Relationships between composting and vermicomposting," in VermicultureTechnology Earthworms, Organic Wastes, and Environmental Management, C. A. Edwards, N. Q. Arancon, and R. Sherman, Eds, Taylor \& Francis, New York, NY, USA, pp. $11-25$.

Adityo, H., L.D. Mahfudz dan V. D. Y. B. Ismadi. 2013. Pengaruh Penggunan Tepung Buah Jambu Biji Merah (Psidium guajava L.) Dalam Ransum Terhada Perlemakan Ayam Broiler. Anima AgriculturalJurnal, Vol. 2. No.2 Hal 41-48.

Hidayati Y. A., E. Harlia dan E. T. Marlina. 2008. Upaya Pengolahan Feses Domba dan Limbah Usar (Vitiveria Zizanioides) Melalui Berbagai Metode Pengomposan. Jurnal Ilmu Ternak, Vol. 8, No. 1, Hal 87 - 90 .

Khan, A. and Ishaq, F. 2011. Chemical nutrient analysis of dif- ferent composts (Vermicompost and Pitcompost) and their effect on the growth of a vegetative crop Pisum sativum. Asian Journal of Plant Science and Research, 1(1),116-130. 
Kuczynski, T. 2002. The Application of Poultry Behaviour Responses On Heat Stress to Improve Heating and Ventilation Systems Efficiency. Electr. J. Pol. Agric. Univ. 5:1-11.

Mashaly, M.M., G.L. Hendrick, MA. Kalama, A.E. Gehad, A.O. Abbas and P.H. Patterson. 2004. Effect Of Heat Stress On Production Parameters and Immune Responses of Laying Hens. J.Poult.Sci. 83: 889-894.

Mbouobda, H. D., Fotso, F. O. T. S. O., Djeuani, C. A., Baliga, M.O., \& Omokolo, D. N. 2014. Comparative evaluation of enzyme activities and phenol content of Irish potato (So- lanum tuberosum) grown under EM and IMO manures Bokashi. International Journal of Biological and Chemical Sciences, 8(1), 157-166

Musnamar, E.I. 2007. Pupuk Organik (Cair dan Padat, Pembuatan, Aplikasi). Penebar Swadaya. Jakarta.

Nur, T., A. R. Noor, dan M. Elma. 2012. Pembuatan Pupuk Organik Cair Dari Sampah Organik Rumah Tangga Dengan Penambahan Bioaktivator Em (Effective Microorganisms.Jurnal Konversi, Volume 5 No. 2, Oktober 2016

Parimin, S. P. 2005. Jambu Biji (Budi Daya dan Ragam (Pemanfaatannya). Penebar Swadaya, Jakarta.

Rao, A.V and S. Agarwal. 2000. Role of antioxidant lycopene in cancer and heart disease. J. Am. College Nutr., 19 (5): 563-569.
Rasyaf, M. 2000. Panduan Beternak Ayam Pedaging. Penerbit Penebar Swadaya, Jakarta.

Saravanan, P., Kumar, S. S., and Ajithan, C. 2013. Eco-friendly Practice of Utilization of Food Wastes. International Journal of Pharmaceutical Sciences Innovation, 14-17.

Sharma, A., Sharma, R., Arora, A., Shah, R., Singh, A., Pranaw, K., and Nain, L. 2014. Insights into rapid composting of paddy straw augmented with efficient microorganism consortium. International Journal of Recycling of Organic Waste in Agriculture, 3(2), 1-9.

Sian Ho Litra Bikrisima, Luthfi D. Mahfudz dan Nyoman Suthama. 2014. Kemampuan Produksi Ayam Broiler Yang Diberi Tepung Jambu Biji Merah Sebagai Sumber Antioksidan Alami. Jurnal Ilmu dan Teknologi Peternakan. Vol. 3 No. 2. Hal 69-75.

Siregar, K.A. 2012. Pemanfaatan Seresah Daun Sebagai Bahan Pembuat Kompos. Universitas Sumatera Utara, Medan.

Stofella, P.J. and B.A. Kahn. 2001. Compost Utilization in Horticultural Cropping System. Lewis Publishers, London.

Sutedjo, M.M., A.G. Kartasapoetra, dan Rd. S. Satroatmodjo. 1996. Mikrobiologi Tanah. PT. Rhineka Cipta. Jakarta.

Telci, I., E. Bayram, G. Yilmas, and B. Avci, 2006. Variability in essential oil composition of Turkish basils. Biochemical Systematics and Ecology Journal. 34:489-497. 